\title{
A FUZZY EXPERT SYSTEM FOR DIAGNOSIS AND TREATMENT OF MUSCULOSKELETAL DISORDERS IN WRIST
}

\author{
Fatemeh Mohammadi Amiri, Ameneh Khadivar
}

Original scientific paper

Medical expert system is an application which can effectively contribute to decisions on diagnosis and treatment of diseases. A major part of the knowledge related to diagnosis of symptoms and treatment of illnesses is experimental. The problem is that how this knowledge can be extracted and made available to others. The purpose of this study is to design an expert system for diagnosis and treatment of musculoskeletal disorders in wrist in fuzzy environment.The knowledge is achieved from 15 elites in the field of musculoskeletal disorders. For data gathering related to symptoms of the disorders, a fuzzy Delphi method is used. A Delphi method is also used for gathering data related to treatments. Finally, a fuzzy expert system is developed for diagnosis and treatment of musculoskeletal disorders in wrist using MATLAB software. The designed system is able to diagnose seven disorders of the wrist. The input to the system is the magnitude of symptoms and the output is the scores given by the system to disorders; finally, the disorder with the highest score is displayed as the systemic diagnosis for which treatments are suggested.The systemic diagnosis is compared to elite diagnosis using statistical analysis conducted by SPSS software. Results show a significant correlation between two variables. By comparing the variables, it is found that $86,7 \%$ of the systemic diagnoses were similar to elite diagnoses. In the absence of elites, diagnosis and treatment can be performed to a relatively reliable level. As results of current research, medical expert systems can be used as a scientific source by medical students. It can also help users as an auxiliary diagnostic system to diagnose and treat diseases.

Keywords: fuzzy approach; knowledge acquisition; medical expert system; musculoskeletal disorders; treatment

Fuzzy ekspertni sustav za dijagnozu i liječenje mišićnoskeletnih poremećaja u ručnom zglobu

Izvorni znanstveni članak

Medicinski ekspertni sustav je aplikacija koja može značajno pomoći pri odlučivanju o dijagnozi i liječenju bolesti. Veći dio znanja koje se odnosi na dijagnozu simptoma i liječenje bolesti je eksperimentalan. Problem je kako to znanje ekstrahirati i učiniti dostupnim drugima. Svrha ovoga rada je napraviti ekspertni sustav za dijagnozu i liječenje mišićno skeletnih poremećaja u ručnom zglobu u fuzzy okruženju. Iskustvo se steklo od 15 elitnih stručnjaka iz područja mišićnoskeletnih poremećaja. Za prikupljanje podataka o simptomima poremećaja primijenjena je fuzzy Delphi metoda. Ta se metoda primijenila i za dobivanje podataka o liječenju. Konačno, razvijen je fuzzy ekspertni sustav za dijagnosticiranje i liječenje mišićno skeletnih poremećaja u ručnom zglobu primjenom softvera MATLAB. Moguće je dijagnosticirati sedam poremećaja zgloba primjenom toga sustava. Ulaz u sustav je magnituda simptoma, a izlaz su rezultati koje je sustav pronašao za te poremećaje; konačno se prikazuje poremećaj s najviše prikupljenih bodova kao sustavna dijagnoza za koju se predlaže liječenje. Ta se dijagnoza uspoređuje s elitnom dijagnozom uz primjenu statističke analize dobivene SPSS softverom. Rezultati pokazuju značajnu korelaciju između dviju varijabli. Usporedbom varijabli ustanovilo se da je $86,7 \%$ sustavnih dijagnoza slično elitnim dijagnozama. U nedostatku elita, dijagnoza i liječenje se mogu postaviti relativno pouzdano. Rezultati ovog istraživanja su pokazali da se studenti medicine mogu koristiti medicinskim ekspertnim sustavima u znanstvene svrhe. Oni mogu također pomoći korisnicima kao pomoćni dijagnostički sustav u dijagnozi i liječenju bolesti.

Ključne riječi: fuzzy pristup; liječenje; medicinski ekspertni sustav; mišićno skeletni poremećaji; stjecanje znanja

\section{Introduction}

Research in artificial intelligence began in 1940s when the first generation of computers emerged in research associations. In 1956, the term artificial intelligence was first used by Professor McCarthy. He defined artificial intelligence as science and engineering to create intelligent machines, particularly intelligent computer programs. This science uses computers to understand human intelligence. Applications developed for games were the first academic attempts for artificial intelligence. The real goal was to determine a better understanding of how to encode human reasoning capabilities by the computer.

Knowledge-based systems or computer programs, involving knowledge to the end users, have been widely used in the field of artificial intelligence. There are several definitions for expert systems; a number of them are given below [1].

Fiegenbaum defined expert system as an intelligent computer program requiring expert knowledge obtained by knowledge acquisition methods to solve complex problems [1].

An expert system is a computer-based interactive decision tool used to solve problems related to difficult decisions using facts and knowledge acquired from experts [2].

An expert system is a computer program mimicking the elite ability to make decisions [3].

The purpose of these definitions is the same, that is, expert systems actually model the knowledge and reasoning of elite. Elite knowledge is a very specific knowledge on a problem involving facts, concepts and relationships. Elite reasoning is actually a process conducted by the elite on information available for a problem to conclude [1].

The level of elite knowledge varies in the field of musculoskeletal disorders. In addition, not anyone can access to elites. Considering the objectives of public health policies that all persons shall have access to health facilities, the knowledge of elites who are usually in large cities can be accessed in remote areas.

A majority of knowledge related to diagnosis of symptoms and treatment of diseases is experimental. The problem is how to extract this knowledge and make available for others.

The expert system can be developed in various areas. One of its applications is expert system in medical sciences. To achieve accurate results, the expert system mimics conclusions of an elite physician systematically. 
Since none of the previous expert systems is designed for musculoskeletal disorders, this study used the expert system to extract the elite knowledge in the field of musculoskeletal disorders.

Considering the ambiguous nature of this knowledge, certain approaches cannot be used to develop this system. Thus, a fuzzy expert system can be a good idea to solve this problem.

The purpose of this study was to develop an expert system for diagnosis and treatment of musculoskeletal disorders by a fuzzy approach. This study finds the macro-architecture of expert system for diagnosis and treatment of musculoskeletal disorders and the relationships between its components. In addition, this study tries to find out whether this system is reliable to replace the experts in diagnosis and treatment of musculoskeletal disorders.

Section 2 describes the medical expert systems and their application in modern world, reviews the relevant literature and explains fuzzy systems. Section 3 describes the methodology including population, data collection methods such as fuzzy Delphi method and Delphi method. Section 4 presents the output of the fuzzy Delphi method based on which the suggested expert system and its different parts including input, output, fuzzy rules, graphic interface and its application are developed. Using pairwise comparisons, correlation test and calculation of systemic error, the system is validated in Section 5. Finally, the results derived from the system, its advantages and remarks for future studies are presented in the last section.

\section{Literature review}

\subsection{Medical expert systems}

Artificial intelligence is a computerized science which studies the feasibility of intelligent systems with capabilities of experts by combining hardware and software. Expert system is a branch of artificial intelligence which stores expert capabilities in a certain context to take decision or find a proper solution into a computerized program. Accordingly, expert system helps experts in a certain field. Expert system can help users who are less experienced in solving problems to take a decision as experts do [4]. Advantages of expert system may include the increased reliability, reduced error, reduced cost, different expertise, smart databases etc. [5, $6]$.

Complexity, ambiguity and diversity existing in certain medical problems prevent the simple process of medical information. Therefore, it is essential to consider decision making for using computers in medicine [7].

Computer-based methods are increasingly used to improve the quality of medical services using artificial intelligence models [8]. Computer technology can reduce mortality using proper diagnostic methods in the early stages of treatment. When a patient refers to a physician, the assumed disease makes the physician to collect information such as patient history, physical examination and laboratory data. By this information and the knowledge regarding the disease, the physician considers the most likely diseases and diagnoses one or more diseases by collecting further information. However, diagnosis is a complex and important process [9].

A medical expert system is a computer program which effectively aids in decisions on diagnosis and treatment of diseases, when properly implemented. Diagnosis and prognosis is conducted as soon as the program receives patient information. This information is usually transmitted through the patient to the physician. Medical expert systems have characteristics which distinguish them from other medical applications. One aspect of this difference is that these systems mimic the conclusions of an elite physician to achieve accurate results. In most cases, a specialist of this software is aware of these consecutive conclusions. Obviously, expert systems require a large number of rules and facts of medical sciences in the field of diseases and conditions to provide an accurate result [10].

In general, an expert system is comprised of the following components:

- Knowledge base includes structured data to encode medical knowledge;

- Inference engine includes procedures to use knowledge and directs the rules in the knowledge base;

- Working memory protects data and facts when the program runs;

- User interface provides an interface between the system and application for effective use;

- Description mechanism explains the results and tracks rules used to achieve results [2];

- Elites, the expert system needs to acquire their knowledge to insert into the knowledge base;

- User uses the expert system;

- Knowledge engineering collaborates the elite to shape subject knowledge to be transferred to the computer [11];

- Knowledge acquisition utilities allow adding, editing and deleting rules in the knowledge base [2]

An expert system is developed in six phases:

- Phase 1: Defining the problem,

- Phase 2: Acquiring the knowledge,

- Phase 3: Designing the system (knowledge representation, control, software of expert system, prototype, user interface, the final product),

- Phase 4: Testing and evaluating the system,

- Phase 5: Documenting

- $\quad$ Phase 6: Maintaining [12].

In recent years, many expert systems have been developed in various fields of medical science, a few examples of which are given in Tab. 1.

\subsection{Fuzzy expert system}

Fuzzy logic was first introduced by Zadeh (1965). In 1971, Zadeh published the quantitative fuzzy semantics which led to the development of fuzzy logic method and its applications. Fuzzy logic is used in many contexts including artificial intelligence programs $[26,5]$.

Fuzzy expert system is inferior to rules of linguistic variables or fuzzy numbers which are uncertain in nature [27]. 
The nature of elite views on something specific is unmeasurable and ambiguous; thus, they cannot be expressed by numerical values. This is where it seems essential to use linguistic variables, because elites can express their views in the form of words [28].

Table 1 Previous expert systems and their applications

\begin{tabular}{|c|c|}
\hline Developed systems & Applications \\
\hline Mycin [13] & $\begin{array}{l}\text { Choice of antibiotics for infectious } \\
\text { diseases }\end{array}$ \\
\hline PUFF [14] & $\begin{array}{l}\text { Automatic interpretation of } \\
\text { pulmonary functioning tests }\end{array}$ \\
\hline MEDI [15] & Medical diagnostic systems \\
\hline DXplain [16] & Decision support in medicine \\
\hline PIERS [17] & Interpretation of pathology reports \\
\hline RENOIR [18] & The diagnosis of 37 joint diseases \\
\hline DIABETES [19] & $\begin{array}{l}\text { Insulin dose adjustment for patients } \\
\text { with diabetes }\end{array}$ \\
\hline RMDS [20] & Diagnosis of renal masses \\
\hline Cadosa [21] & $\begin{array}{l}\text { Diagnosis of breathing disordered in } \\
\text { sleep }\end{array}$ \\
\hline MIMIC [22] & Decision support system in ICU \\
\hline $\begin{array}{l}\text { Diagnosis of heart valve } \\
\text { disease [23] }\end{array}$ & Diagnosis of heart valve diseases \\
\hline Pig-vet [24] & Diagnosis of pig disease \\
\hline $\begin{array}{l}\text { Diagnosis and treatment } \\
\text { of leukemia [10] }\end{array}$ & $\begin{array}{l}\text { Diagnosis and recommended } \\
\text { treatment for leukemia }\end{array}$ \\
\hline IX-DBC [3] & Diagnosis of breast cancer \\
\hline Code $[25]$ & Coronary artery tests \\
\hline $\begin{array}{l}\text { Proper nutrition } \\
\text { diagnosis expert system } \\
{[2]}\end{array}$ & $\begin{array}{l}\text { Diagnosis of proper nutrition for } \\
\text { patients }\end{array}$ \\
\hline
\end{tabular}

Another concept that often arises in connection with fuzzy systems is the concept of fuzzy variables. Value of a fuzzy variable is expressed by words, phrases and statements. For example, Communication Skills is a linguistic variable; its linguistic values can be good, medium or poor. Any linguistic variable can be attributed a fuzzy membership function [29].

The structure of fuzzy expert system consists of four main sections:

Fuzzification converts the real numbers to fuzzy sets, knowledge base includes laws which express the relationship between input and output fuzzy variables [30], inference mechanism takes input from user, selects the rules from the rule base [25], processes the input based on these rules and provides the output [30], defuzzification converts the fuzzy set to a real number based on the defuzzification process [31]. Another important concept of fuzzy expert system is knowledge acquisition which provides an efficient means of knowledge collection and storage throughout the world.

Inference rules defined in the inference engine must comply with the information in the knowledge base to make correct predictions [5].

\section{$3 \quad$ Research methodology}

The general orientation of this study is appliedextended. The used methodology is mixed (hybrid). Due to the large volume of information including symptoms and treatment of musculoskeletal disorders and limited time of elites to share this information, symptoms and treatment of musculoskeletal disorders were extracted from references in this field (common musculoskeletal disorders [32] and orthopedic physical assessment [33]) introduced by elites. Using fuzzy Delphi method, elite views on the symptoms of musculoskeletal disorders were collected. Considering the experience of elites in this field, the elites were asked to add other symptoms and treatments for these disorders, if any exist, and express the extent of those symptoms. Other elites were provided by the symptoms added in the second step of fuzzy Delphi and asked to express their views. However, Delphi method was used to collect the elite views due to the certain nature of treatment.

Using the information obtained from the previous step, the knowledge base and fuzzy rules thereby expert system of diagnosis and treatment of musculoskeletal disorders were developed. The main hypothesis of this study is that the developed system is validated; that is, the diagnosis of expert system matches the elite diagnosis. To test this hypothesis, paired comparison test, correlation test and system errors were used. The main limitation of this study was limited time of elites to provide their knowledge, which needed time to be accurate when responding to questionnaires.

\subsection{Population and sample}

One of the most important steps in developing expert systems is to develop a rich knowledge base; hence, the required knowledge was acquired from elites and theorists of the field to develop this knowledge base. Therefore, the population studied here is elites.

Depending on the design-description type of the study, the used methodology to select elites was convenient sampling. In other words, a number of available elites who were able to work with the project were used. The survey was conducted among elites with the following conditions:

A master's degree or $\mathrm{PhD}$

Educated in the field of physiotherapy

Experience in the clinical environment, i.e. constantly dealing with patients with musculoskeletal disorders

Preferably a professor or teaching faculty in an academic environment

Totally, 15 people were willing to participate in the study.

\subsection{Methods and materials}

Initially, library and Internet resources such as books and papers were used to gather literature and theoretical background. Available books and resources were used to acquire the knowledge required for the expert system. Professionals and elites, both on campus teaching this science and in the clinical environment diagnosing and treating these disorders, were asked to participate. To gather elite views on diagnosis of symptoms, the fuzzy Delphi method was used. The Delphi method was also used for treatments of musculoskeletal disorders.

Considering the fuzzy nature of diagnosis, fuzzy Delphi was used to gather information on symptoms which ultimately lead to diagnosis. In the first step of fuzzy Delphi method, 15 elites were selected and justified on the subject, method and duration of the study. The 
elites were asked to score the symptoms by responding to options ranging from low, average or high. They were also asked to add those symptoms which are required to be added to the symptoms extracted from books. By fuzzy averaging of elite responses in the first step, a separate questionnaire was developed for each elite. The questionnaire contained the items of the first step, each followed by statistics of the first step including the number of responses to each option as well as the elite responses in the previous step. The elites were asked to respond to the added symptoms. By fuzzy averaging of the responses in the first and second steps and comparing the averages, the elite responses were recorded, if acceptably stable; otherwise, the third step of survey was conducted. This process continued until all responses were stable (three iterations). In the second step, the elites were suggested that, if possible, their responses in this step be closer to the average of responses in the previous step. In the third step, they were also recommended to repeat the same response if they were sure of the previous response. However, it is noteworthy that elites were free in responding and researchers could only offer suggestions.

Because of the certain nature of treatment, the Delphi method was used. The treatment questionnaire was in the form of yes or no options. Initially, the treatments were extracted from Treatment of Common Musculoskeletal Disorders and Orthopedic Physical Assessment. Elites were asked to express their views and add other treatments, if they exist. Then, elites were provided by separate questionnaires in which the first items were repeated, each followed by statistics of the first responses including the number of elite responses to each item as well as the elite response in the previous stage. The elites were asked to respond to added symptoms. In this research, the responses were stable by two iterations.

Table 2 Membership functions of inputs related to symptoms of carpal tunnel syndrome

\begin{tabular}{|c|c|}
\hline $\begin{array}{l}\text { 1) Paresthesia in the first } 3 \text { or } \\
4 \text { fingers } \\
\text { Low: }(6 ; 8 ; 8,5) \\
\text { Medium: }(8 ; 9 ; 10) \\
\text { High: }(9,5 ; 10 ; 10)\end{array}$ & $\begin{array}{l}\text { 6) Positive tinel test on carpal } \\
\text { tunnel } \\
\text { Low: }(0,8 ; 1,1 ; 1,6) \\
\text { Medium: }(1,1 ; 2,1 ; 3,1) \\
\text { High: }(2,6 ; 3,1 ; 4,8)\end{array}$ \\
\hline $\begin{array}{l}\text { 2) Awaking at night because } \\
\text { of paresthesia } \\
\text { Low: }(5,8 ; 7,7 ; 8,2) \\
\text { Medium: }(7,7 ; 8,7 ; 9,7) \\
\text { High: }(9,2 ; 9,7 ; 9,8)\end{array}$ & $\begin{array}{l}\text { 7) Positive modified phallen } \\
\text { test } \\
\text { Low: }(5,4 ; 7,2 ; 7,7) \\
\text { Medium: }(7,2 ; 8,2 ; 9,2) \\
\text { High: }(8,7 ; 9,2 ; 9,4)\end{array}$ \\
\hline $\begin{array}{l}\text { 3) Paresthesia with long } \\
\text { finger flexion } \\
\text { Low }(6 ; 8 ; 8,5) \\
\text { Medium: }(8 ; 9 ; 10) \\
\text { High: }(9,5 ; 10 ; 10)\end{array}$ & $\begin{array}{l}\text { 8) Positive reverse phallen test } \\
\text { Low: }(6 ; 8 ; 8,5) \\
\text { Medium: }(8 ; 9 ; 10) \\
\text { High: }(9,5 ; 10 ; 10)\end{array}$ \\
\hline $\begin{array}{l}\text { 4) Thenar atrophy } \\
\text { Low: }(0,4 ; 0,5 ; 1) \\
\text { Medium: }(0,5 ; 1,5 ; 2,5) \\
\text { High: }(2 ; 2,5 ; 4,4)\end{array}$ & $\begin{array}{c}\text { 9) Positive carpal compression } \\
\text { test } \\
\text { Low: }(3,2 ; 4,3 ; 4,8) \\
\text { Medium: }(4,3 ; 5,3 ; 6,3) \\
\text { High: }(5,8 ; 6,3 ; 7,2)\end{array}$ \\
\hline $\begin{array}{l}\text { 5) Thenar muscle weakness } \\
\text { Low: }(1 ; 1,3 ; 1,8) \\
\text { Medium: }(1,3 ; 2,3 ; 3,3) \\
\text { High: }(2,8 ; 3,3 ; 5)\end{array}$ & $\begin{array}{l}\text { 10) Positive ULTT of median } \\
\text { nerve } \\
\text { Low: }(3,6 ; 4,8 ; 5,3) \\
\text { Medium: }(4,8 ; 5,8 ; 6,8) \\
\text { High: }(6,3 ; 6,8 ; 7,6)\end{array}$ \\
\hline
\end{tabular}

The results show seven disorders for the wrist. The final ranges obtained from the fuzzy Delphi method, related to symptoms of carpal tunnel syndrome in wrist are listed in Tab. 2.

Treatments of wrist carpal tunnel syndrome derived from the Delphi method include nonsteroidal antiinflammatory drugs, daily living adjustment, bracing, nerve glide exercises, tendon glide exercises, carpal tunnel soft tissue manipulation, carpal radio joint distraction, pisotriquetral joint mobilization, strengthening exercises, taping, TENS, ultrasound and laser.

\section{Results \\ 4.1 Development of a fuzzy expert system for diagnosis and treatment of musculoskeletal disorders}

The proposed system which was tested in this study is an expert system of diagnosis and treatment of musculoskeletal disorders, as presented in Fig. 1. Components of the model include knowledge base (based on fuzzy rules and the database which involves input functions including symptoms and output including disorders), inference engine (including fuzzy inference and Mamdani inference relation), interface (including the graphical user interface designed in MATLAB) and knowledge acquisition utilities (to delete, add or edit the knowledge base).

The fuzzy logic toolbox in MATLAB was used to develop the expert system. First, the initial setup related to operators and configurations of the input and output variables was identified. Fig. 2 shows the configuration related to the number of some inputs and outputs and the number of rules as well as operators.

As noted, the input and output of the system were symptoms and the type of disorder diagnosed by the system, respectively. There were seven disorders related to wrist; therefore, there were seven outputs. The number of inputs was the number of symptoms of this disorder. Therefore, diagnosis was made based on the score given by the system to symptoms regarding the sum of the scores. Systemic diagnosis was a disorder with the highest score. Fig. 3 shows an overview of the expert systems in MATLAB.

\subsection{Input functions of the expert}

For each input variable, three membership functions were defined:

- Low membership function

- Average membership function

- High membership function.

In this system, the functions were triangular; the functions out of the range defined by the elite were trapezoidal.

Considering the ranges obtained from fuzzy Delphi, diagrams of the membership functions were drawn for the input variables of wrist. To increase flexibility, the membership function was defined for any variable. 


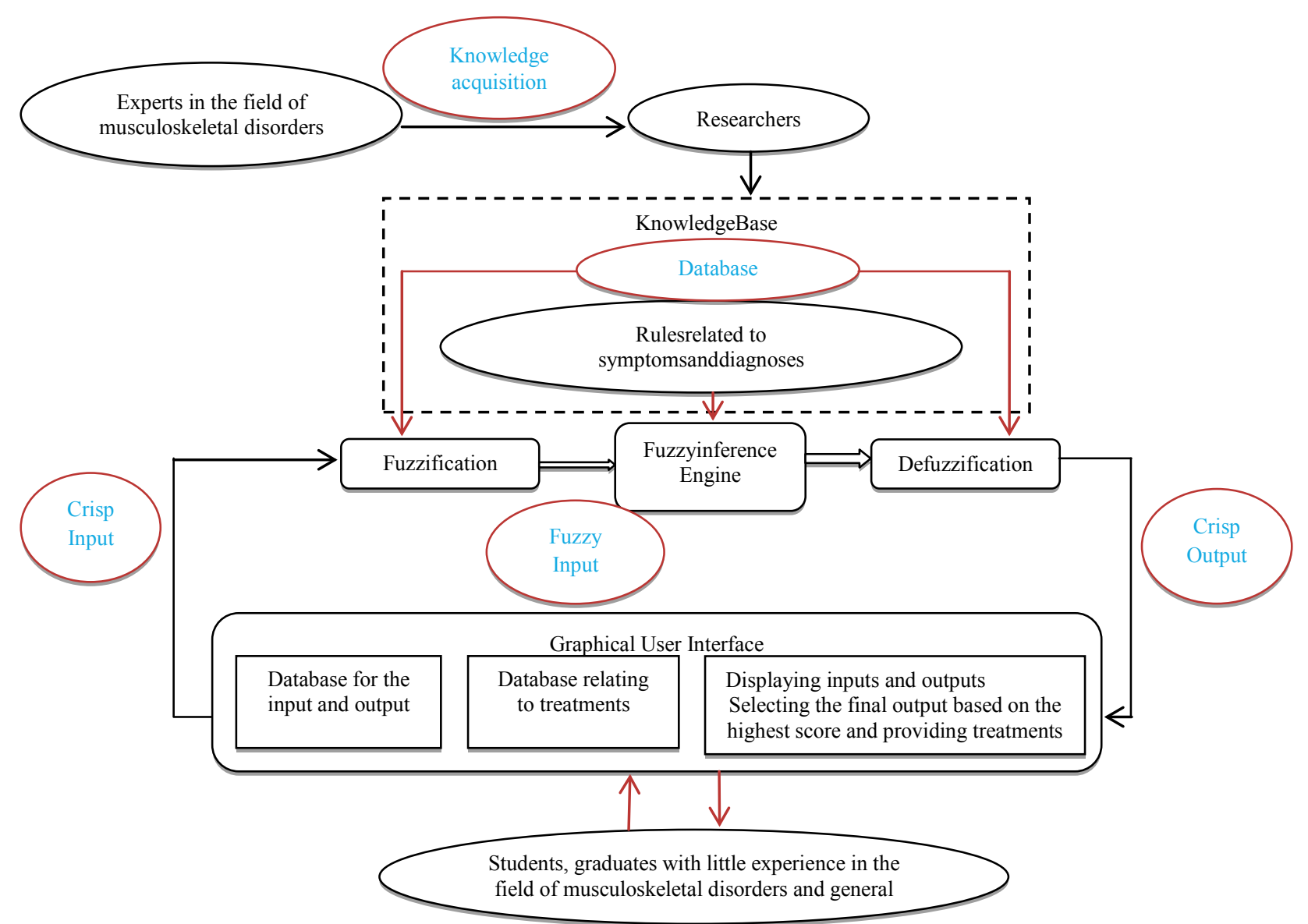

Figure 1 The expert system of diagnosis and treatment of musculoskeletal disorders

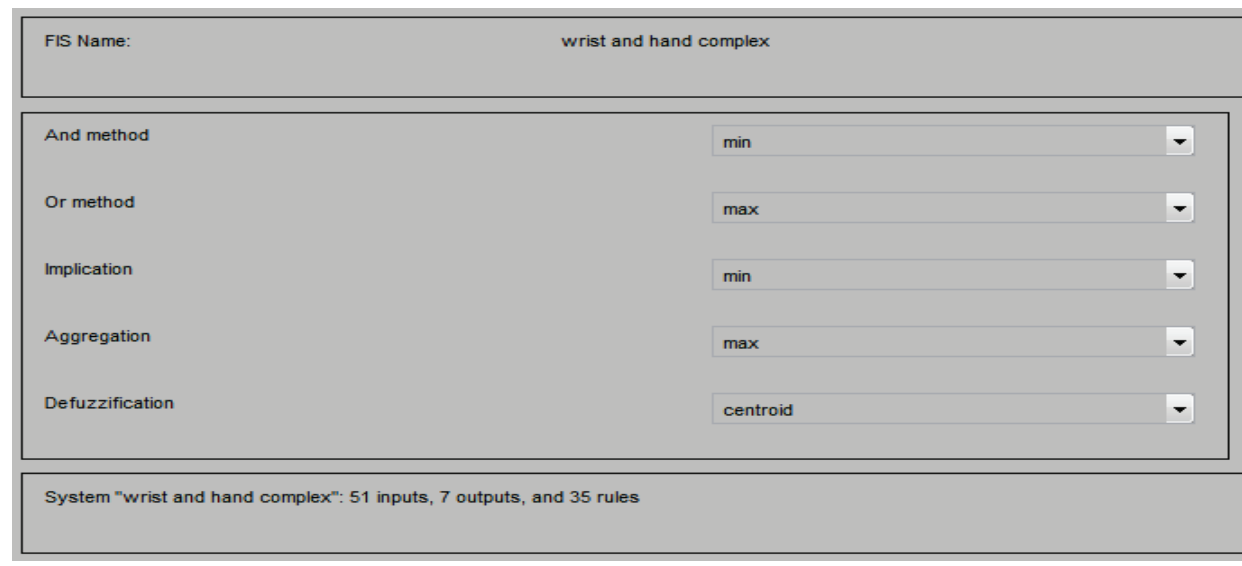

Figure 2 settings of the proposed expert system in MATLAB

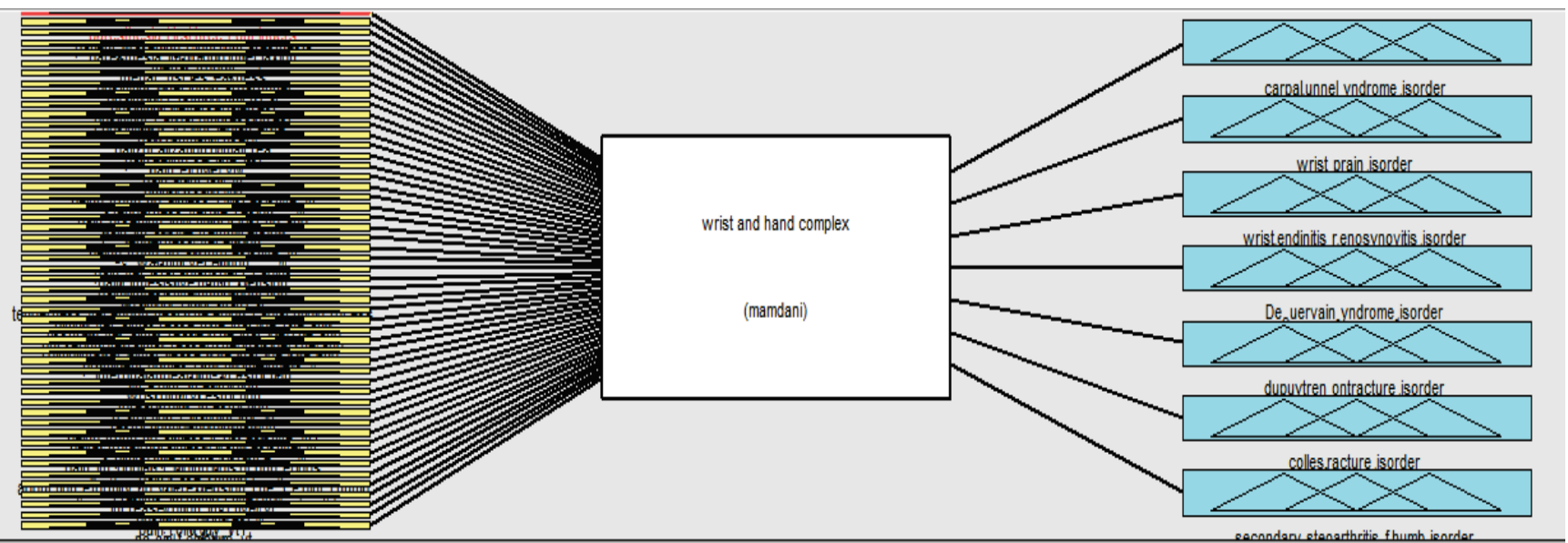

Figure 3 Overview of the expert system of diagnosis and treatment of musculoskeletal disorders of the wrist 
In Fig. 4, indicating a symptom of wrist carpal tunnel syndrome, the triangular membership functions were defined for inputs ranging from 0 to 10 ; the range was derived from elite views. Trapezoidal membership functions were defined for symptoms out of the allowable range. The symptoms which were less or more than the allowable range (out of the range specified in green) were assigned the zero value by the rules in the knowledge base.

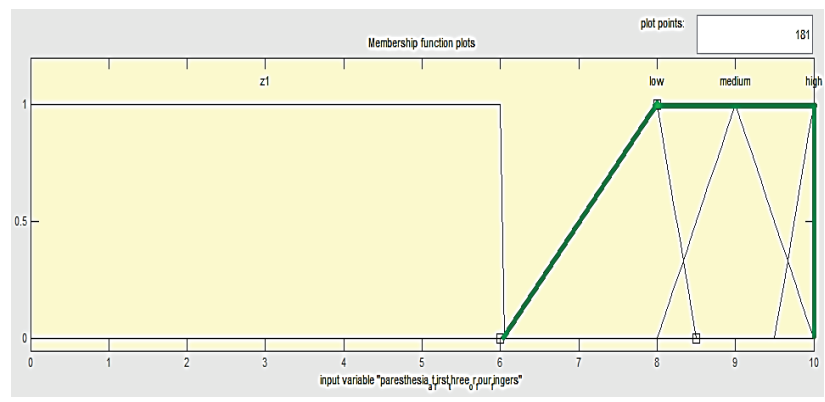

Figure 4 Membership function related to paresthesia symptom in the first 3 or 4 fingers

\subsection{Fuzzy rule base}

To set the rules, all possible scenarios were considered for inputs; then, corresponding outputs were determined as scenarios of inputs. By receiving inputs, the fuzzy expert system made necessary inferences using these rules and presented the output as fuzzy variables.

This kind of inference is expressed as fuzzy rules in MATLAB. The numbers in parentheses in front of rules are weight of rules, which were here considered equal to one. Rules related to wrist carpal tunnel syndrome are given in the knowledge base in the Appendix.

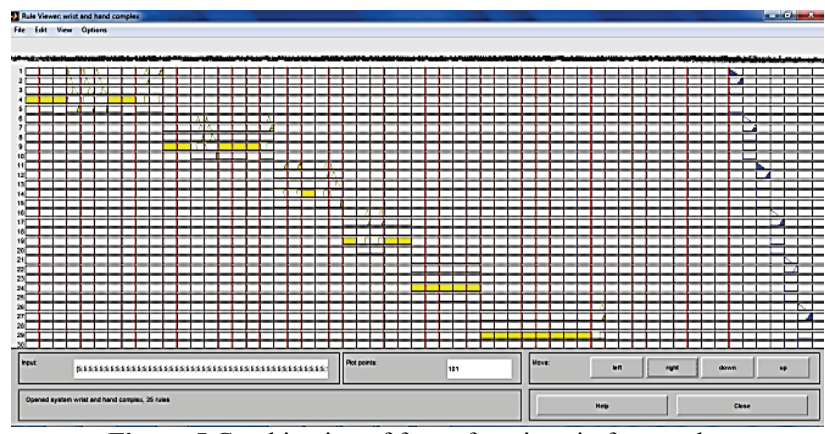

Figure 5 Combination of fuzzy functions in fuzzy rules

There were seven wrist disorders; therefore, the knowledge base included 35 fuzzy rules. Fig. 5 shows an overview of the combination of fuzzy functions in knowledge base. As shown in Fig. 5, the input values for qualitative variables varied from $0 \div 10$ from the user. By combining the fuzzy rules and defuzzification, the result was expressed in the form of a score given to seven disorders. Defuzzification refers to the shift from fuzzy output of the inference engine to certain output using the membership functions [34]. Fuzzy sets emerged from combined results of rules are defuzzified by defuzzification methods such as Center of Gravity, Max membership, Mean-Max and Weighted average. Center of Gravity is the most common method which here calculates the range of the numerical solution by calculating the Center of Mass. In this method, the defuzzified value of the fuzzy set $A, \mathrm{~d}(A)$, is calculated by the following formula, where, $\mu(A)$ is the membership function of fuzzy set $A$ [35].

$$
\frac{\int_{A} X \mu A(x) \mathrm{d} x}{\int_{A} \mu A(x) \mathrm{d} x} .
$$

\subsection{Output functions of the expert system}

The proposed expert system provided seven outputs which are the same wrist disorders. In this system, the triangular and trapezoidal functions were used. For input value in the allowable range, the output was mapped on a triangular function defined on the scale of $0 \div 30$. For input-assigned scores out of the allowable range, the score was mapped on the output membership function, zero. The trapezoidal function was used for output membership functions out of the range of $0 \div 30$. Fig. 6 shows the membership functions of output variable for wrist disorders. Because of the similar membership functions of output variables, only the output related to one disorder is shown.

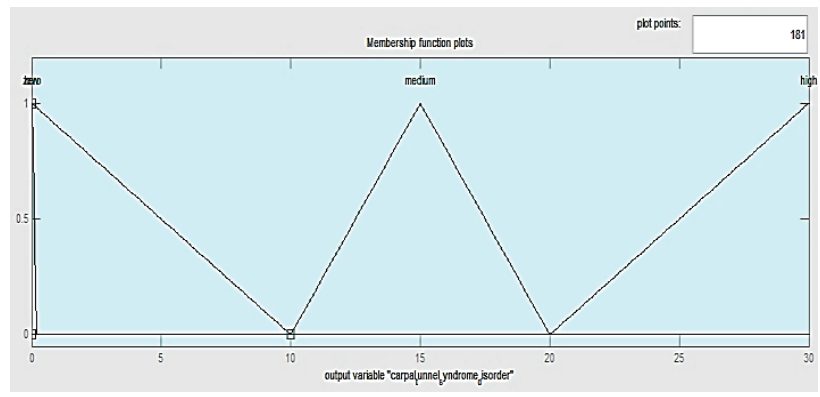

Figure 6 Membership functions of output variable for carpal tunnel syndrome

\subsection{Graphical user interface}

User interface refers to a series of forms, reports and utilities which are used by the user to input, edit, and display information to the expert system. User interface of the proposed system was used as a shell between the user and the proposed system. All information to be acquired from the user was inserted through graphical forms embedded in the interface; by processing in intelligent engine system, the result was sent to the user interface and reports embedded in the user interface were displayed to the user via forms. Fuzzy inference is process of mapping inputs to outputs through fuzzy logic. In this research, the software MATLAB was used to develop a graphical user interface. Graphical user interface is a set of tools which allows the developer to simply develop a graphical user interface in order to increase interaction between user and fuzzy inference system.

\subsection{Procedure}

Using the graphical user interface of the proposed system, the user began by the form shown in Fig. 7. The user could insert the input numbers related to the size of 
each symptom. Inputs and outputs were displayed on the left side and the right side of the form.

By inserting the inputs and pressing the run button, the numbers were inserted into the inference engine of the selected expert system for fuzzy inference. The result was inserted into the shell and the score of each output was shown in front of the output in the form. By the program given to the shell, the disorder with the highest score was displayed as the selected output of the system under the condition. Treatment of each disorder was inserted in an Excel file of which the shell retrieved the treatments and displayed under the recommended treatment. Fig. 8 shows an example of the system.

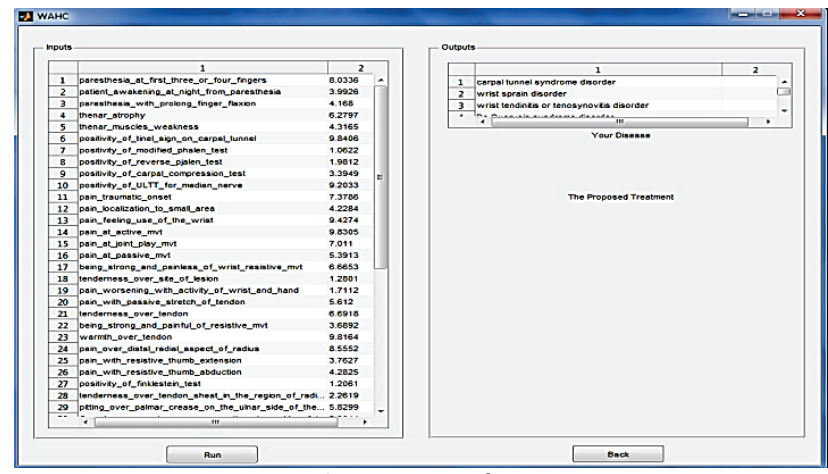

Figure 7 Input form

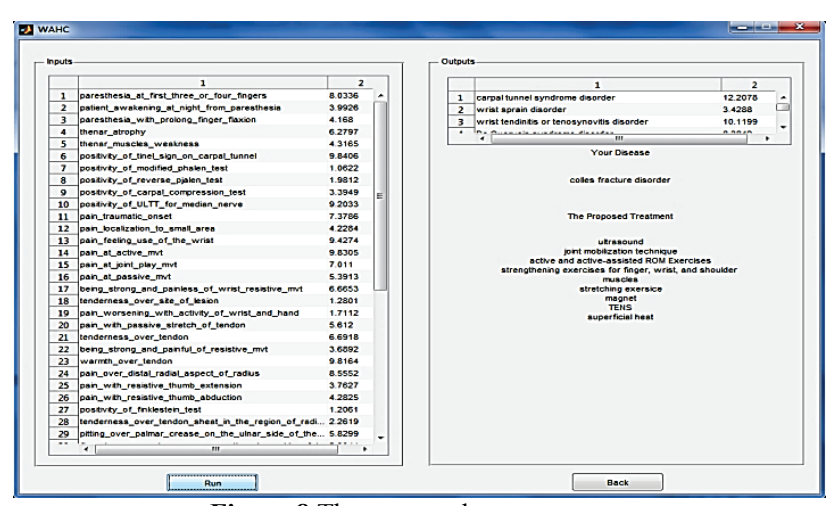

Figure 8 The proposed expert system

\section{Validation}

For validation of knowledge available in the knowledge base, this study used Delphi method and fuzzy Delphi for consensus between elites about the symptoms and treatment of disorders. In this section, the validation of the system is discussed.

The first major purpose of the validation is to check two special cases in which all symptoms are set to 0 or to 10. In the first case, the system will give zero to all outputs as the final result which is reasonable; while, when all the symptoms are set to 10 , the final result to all outputs will not be equal to the last output value (30) and will be equal to 25,2923 . This is because of the upper limit for the symptoms, derived from fuzzy Delphi process, which confirms the good performance of the system.

To test and verify the performance of the system, the symptoms related to 30 patients were extracted from medical records at a hospital. Data on patients was inserted into the system for diagnosis. The symptoms were then provided to an expert who stated his diagnosis using the symptoms. Systemic diagnosis and elite diagnosis were analysed by SPSS.

\subsection{Paired comparison test}

As shown in Tab. 3, the significance of the test was $>5 \%$; therefore, the null hypothesis is supported. In other words, there is no significant difference between means of systemic diagnosis and elite diagnosis (5\% error level).

The $95 \%$ confidence interval for the difference between systemic diagnosis and elite diagnosis is as follows: $-0,070 \leq \mu \leq 0,203$.

As lower limit is negative and the upper limit is positive, it can be concluded that there is no significant difference between the means.

Table 3 Results of paired samples

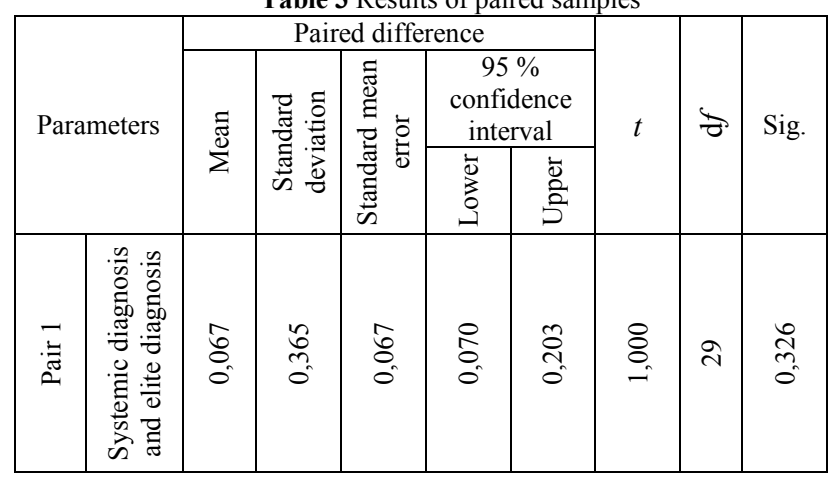

\subsection{Correlation Test}

To investigate the correlation between two variables and obtain the correlation coefficients (Pearson and Spearman), the correlation test was used. The result includes two outputs. The first output (Tab. 4) shows the Pearson correlation coefficient, significance and the number of samples. Based on the output, significance is $<0,05$; therefore, the null hypothesis is rejected and there is a correlation between these two variables. The correlation coefficient is 0,999 for 30 samples.

Table 4 Results of Pearson correlation coefficient

\begin{tabular}{|c|c|c|c|}
\hline \multirow{2}{*}{ Parameters } & $\begin{array}{c}\text { Systemic } \\
\text { diagnosis }\end{array}$ & $\begin{array}{c}\text { Elite } \\
\text { diagnosis }\end{array}$ \\
\hline \multirow{3}{*}{$\begin{array}{c}\text { Systemic } \\
\text { diagnosis }\end{array}$} & $\begin{array}{c}\text { Pearson correlation } \\
\text { coefficient }\end{array}$ & 1 & 0,999 \\
\cline { 2 - 4 } & Significance & & 0,000 \\
\cline { 2 - 4 } Elite diagnosis & Number & 30 & 30 \\
\cline { 2 - 4 } & $\begin{array}{c}\text { Pearson correlation } \\
\text { coefficient }\end{array}$ & 0,999 & 1 \\
\cline { 2 - 4 } & Significance & 0,000 & 30 \\
\cline { 2 - 4 }
\end{tabular}

Table 5 Results of Spearman correlation coefficient

\begin{tabular}{|c|c|c|c|}
\hline \multicolumn{2}{|c|}{ Parameters } & $\begin{array}{c}\text { Systemic } \\
\text { diagnosis }\end{array}$ & $\begin{array}{c}\text { Elite } \\
\text { diagnosis }\end{array}$ \\
\hline \multirow{3}{*}{$\begin{array}{c}\text { Systemic } \\
\text { diagnosis }\end{array}$} & $\begin{array}{c}\text { Spearman correlation } \\
\text { coefficient }\end{array}$ & 1,000 & 0,999 \\
\cline { 2 - 4 } & Significance & & 0,000 \\
\cline { 2 - 4 } & Number & 30 & 30 \\
\hline \multirow{3}{*}{ Elite diagnosis } & $\begin{array}{c}\text { Pearson correlation } \\
\text { coefficient }\end{array}$ & 0,999 & 1,000 \\
\cline { 2 - 4 } & Significance & 0,000 & 30 \\
\cline { 2 - 4 } & Number & 30 & 30 \\
\hline
\end{tabular}


The second output (Tab. 5) presents Spearman correlation coefficient, significance and the number of samples. Results of Spearman method are similar to the results of Pearson $(0,999)$. Note that both of these coefficients are significant at $1 \%$ error.

\subsection{Calculation of errors in the expert system}

This section calculates and compares MAD, MSE, RMSE, MAPE and MPE errors for outputs of the expert system compared to elite diagnosis. The results can be a good indication of accuracy in diagnosis of the expert system. It is noteworthy that the measure of error is comparison of the results provided by the expert system and the results of elite diagnosis (Tab. 6).

The results show that the system has sufficient accuracy to be replaced by an expert. Finally, the comparison of the results shows that $86,7 \%$ of the systemic diagnoses are similar to the elite diagnoses.

Table 6 Results of error measurement

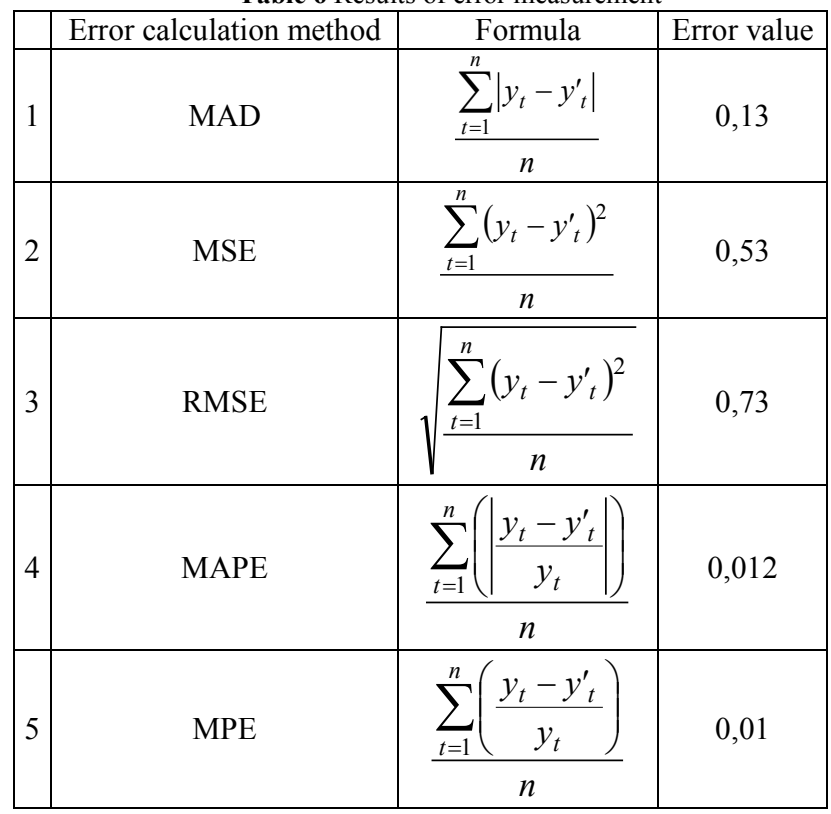

\section{Conclusion}

To compare two variables, paired comparison test was used and output showed a significant correlation between the two variables. No significant difference was found between means of the systemic diagnosis and elite diagnosis at $5 \%$ error level. The Pearson and Spearman correlation coefficients indicated a high correlation between the two variables. MAD, MSE, RMSE, MAPE and MPE errors were calculated to check the output of the expert system compared with elite diagnosis. Error comparison shows that the system has sufficient accuracy in diagnosis of musculoskeletal disorders.

The proposed system is an expert system of diagnosis and treatment of musculoskeletal disorders. Components of this model include knowledge base (based on fuzzy rules), the inference engine (including fuzzy inference and Mamdani inference relation), working memory, interface (including the graphical user interface designed in MATLAB) and knowledge acquisition utilities (to delete, add or edit the knowledge base).
The results of this study show that the proposed system has a good performance in diagnosis and treatment of musculoskeletal disorders. The main advantage of this system compared to the previous systems is that none of the systems developed earlier were related to musculoskeletal disorders and the proposed system in this study was the first in this regard. In addition, Delphi and fuzzy Delphi method were used to gather elite views, while the former medical expert systems did not.

The expert system of diagnosis and treatment of musculoskeletal disorders, developed in this study by fuzzy approach, can be used as the best way to teach medical students. Graduates with little experience in musculoskeletal disorders as well as general practitioners in remote areas can use the system as an adjunctive diagnostic system. It is also recommended to complete the study in future based on the symptoms effective on the disorder and assign weights to them, if necessary. Possible rules in the knowledge base system can be utilized. It is also possible to develop the system based on learning from data. In this case, the system uses the records available in databases to diagnose the disease. Due to the high workload of experts, this study only considered musculoskeletal disorders for the upper part of the body in wrist. It is recommended to consider these disorders for other parts of the body (lower body and spine) for future works.

\section{References}

[1] Bascfitci, F.; Incekara H. Web based medical decision support system application of Coronary Heart Disease diagnosis with Boolean functions minimization method. // Expert Systems with Applications. 38, (2011), pp. 1403714043.

[2] Chen, Y.; Hsu C.h.; Liu, L.; Yang, S. Constructing a nutrition diagnosis expert system. // Expert Systems with Applications. 39, (2012), pp. 2132-56. DOI: 10.1016/j.eswa.2011.07.069

[3] Keles, A.; Keles, A.; Yavuz, U. Expert system based on neuro-fuzzy rules for diagnosis of breast canser. // Expert systems with applications. 38, (2011), pp. 5719-5726. DOI: 10.1016/j.eswa.2010.10.061

[4] Valentina Silitonga, D.; Budiharto, W. An expert system of measurement of individual knowledge for teeth treatment. // International journal of software engineering and its applications. 9, 4(2015), pp. 11-18.

[5] Baghel, K.; Mehta, N. A web based fuzzy expert system for human disease diagnosis. // International journal of engineering and computer science. 4, 9(2015), pp. 1424814253.

[6] Kadhim, M. A.; Afshar Alam, M., Kaur, H. Design and Implementation of Fuzzy expert System of Back Pain Diagnosis. // International Journal of Innovative technology \& Creative Engineering. 1, 9(2011), pp. 16-22.

[7] Rodriguez-Gonzalez, A.; Torres-Nino, J.; Hernandez-chan, G.; Jimenez-Domingo, E.; Alvares-Rodriguez, J. Using agents to parallelize a medical reasoning system based on ontologies and description logics as an application case. // Expert Systems with Applications. 39, 18(2012), pp. 13085-13092. DOI: 10.1016/j.eswa.2012.05.093

[8] Ayangbekun Oluwafemi, J.; Jimoh Ibrahim, A. Expert system for diagnosis neurodegenerative disease. // International journal of computer and information technology. 4, 4(2015), pp. 694-698. 
[9] Frenster, J. H. Expert Systems and Open Systems in Medical Artificial Intellligenc. // Medical Systems and Information. 89, 7(1989), pp. 118-120.

[10] Toloie Ashlaqi, A.; Mohsen Taheri, S. Designing an Expert System for Suggesting the Blood Canser Treatment. // Journal of Health Administration. 13, 40(2010), pp. 41-50.

[11] Szolovits, P.; Patil, R. S.; Schwartz, W.B. Artificial Intelligence in Medical Diagnosis. // Annals of Internal Medicine. 108, (1982), pp. 80-87. DOI: 10.7326/0003-4819108-1-80

[12] Jalote-Parmar, A.; Badke-Schaub, P.; Ali, W.; Samset, E. Cognitive processes as integrative component for developing expert decision-making systems: A workflow centered framework. // Journal of Biomedical Informatics. 43, (2010), pp. 60-74. DOI: 10.1016/j.jbi.2009.07.001

[13] Chabahat, F.; Hansell, D. M.; Yang, G. Z. Computerized decision support in medical imaging. // IEEE Engineering in medicine and Biology Magazine. 19, 5(2000), pp. 89100. DOI: $10.1109 / 51.870235$

[14] Aikins, J. S.; Kunz, J. C.; Shortliffe, E. H.; Fallat, R. J. PUFF: An expert system for interpretation of pulmonary function data. // Computers and Biomedical Research. 16, (1983), pp. 199-208. DOI: 10.1016/0010-4809(83)90021-6

[15] Puppe, B.; Puppe, F. MEDI: An intelligent computer program for thoracic pain diagnosis. // Klinische Wochenschrift. 63, 11(1985), pp. 511-517. DOl: 10.1007/BF01747981

[16] Barnett, G. O.; Cimino, J. J.; Hupp, J. A.; Hoffer, E. P. DXplain an evolving diagnostic decision-support system. // The Journal of the American Medical Association. 258, 1(1987), pp. 67-74. DOI: 10.1001/jama.1987.03400010071030

[17] Edwards, G.; Compton, P.; Malor, R.; Srinivasan, A.; Lazarus, L. PIERS: A pathologist maintained expert system for the interpretation of chemical pathology reports. / Pathology. 25, (1993), pp. 27-34. DOl: 10.3109/00313029309068898

[18] Hernandez, C.; Sancho, J. J.; Belmonte, M. A.; Sierra, C.; Sanz, F. Validation of the medical expert systems RENOIR. // Computers and Biomedical Research. 27, 6(1994), pp. 456-471. DOI: 10.1006/cbmr.1994.1034

[19] Ambrosiadou, B.V.; Goulis, D.G.; Pappas, C. Clinical evaluation of the DIABETES expert systems for decision support by regimen insulin dose adjustment. // Computer Methods and Programs in Biomedicine, 49, (1996), pp. 105-115. DOI: 10.1016/0169-2607(95)01711-9

[20] Chang. P. L.; Li, Y. C.; Huang, S. T.; Wang, T. M.; Hsieh, M. L. Effects of a medical expert system on differential diagnosis of renal masses: A prospective study. // Comput Medical Imaging Graph. 20, 1(1996), pp. 43-48. DOI: 10.1016/0895-6111(96)00029-8

[21] Daniels, J. E.; Cayton, R. M.; Chappell, M. J.; Tjahjadi, T. Cadosa: A fuzzy expert systems for differential diagnosis of obstructive sleep apnoea and related conditions. // Expert Systems with Applications. 12, 2(1997), pp. 163-177. DOI: 10.1016/S0957-4174(96)00091-7

[22] Saeed, M.; Lieu, C.; Raber, G.; Mark, R. G. MIMIC : A massive temporal ICU patient database to support research in intelligent patient monitoring. // Comput Cardiol. 29, (2002), pp. 641-644. DOI: 10.1109/CIC.2002.1166854

[23] Turkoglu, I.; Arslan, A.; Ilkar, E. An expert system for diagnosis of the heart valve diseases. // Expert Systems with Applications. 23, (2002), pp. 229-236. DOI: 10.1016/S0957-4174(02)00042-8

[24] Zetian, F.; Feng, X.; Yun, Z.; XiaoShuan, Z. Pig-vet: a web-based expert system for pig disease diagnosis. // Expert Systems with Applications. 29, (2005), pp. 93-103. DOI: 10.1016/j.eswa.2005.01.011

[25] Pal, D.; Mandana, K. M.; Pal, S.; Sarkar, D.; Chakraborty, C. Fuzzy expert system approach for coronary artery disease screening using clinical parameters. // Knowledge-
Based Systems. 36, (2012), pp. 174-162. DOl: 10.1016/j.knosys.2012.06.013

[26] Krishna Anand, S.; Kalpana, R.; Vijayalakshmi, S. Design and Implementation of a Fuzzy Expert System for Detecting and Estimating the Level of Asthma and Chronic Obstructive Pulmonary Disease. // Middle-East Journal of Scientific Research. 14, 11 (2013), pp. 1435-1444.

[27] Bibi, M.; Nutman, A.; Shoseyov, D.; Shalom, M,; Peled, R,; Kivity, S.; Nutman, J. Prediction of Emergency Department Visits for Respiratory Symptoms Using an Artificial Neural Network. // Chest. 122, 5(2002), pp. 162732. DOI: 10.1378/chest.122.5.1627

[28] Noor-E-Alam, M.; Ferdousi Lipi, T.; Akhtar Hasin, M.; Ullah, A. Algorithms for fuzzy multi expert multi criteria decision making (ME-MCDM). // Knowledge-Base Systems 24, 3(2011), pp. 367-377. DOI: 10.1016/j.knosys.2010.10.006

[29] Kelemenis, A.; Ergazakis, K.; Askounis, D. Support managers' selection using an extension of fuzzy TOPSIS. // Expert Systems with Applications. 38, (2011), pp. 2782-74. DOI: 10.1016/j.eswa.2010.08.068

[30] Uzoka, F. M. E.; Osuji, J.; Obot, O. Clinical decision support system (DSS) in the diagnosis of malaria: A case comparison of two soft computing methodologies. // Expert Systems with Applications. 38, 3(2011), pp. 1537-1553. DOI: 10.1016/j.eswa.2010.07.068

[31] Cochran, J. K.; Chen H. Fuzzy multi-criteria selection of object oriented simulation software for production system analysis. // Computers and Operations Research. 2, 32(2005), pp. 153-168. DOI: 10.1016/S0305-0548(03)00209-0

[32] Hertling, D. M.; Kessler, R. Management of Common Musculoskeletal Disorders: Physical Therapy principles and Method. 4nd ed. Philadelphia: Lippincott Williams \& Wilkins, 2005

[33] Magee, D. J. Orthopedic Physical Assessment. 5nd ed. Canada: Saunders, 2008.

[34] Jain, V.; Raheja, S. Improving the prediction rate of diabetes using fuzzy expert system. // International journal of Information technology and computer science.10, 1(2015), pp. 84-91. DOI: 10.5815/ijitcs.2015.10.10

[35] Haji, A.; Assadi, M. Fuzzy expert systems and challenge of new product pricing. // Computers \& Industrial Engineering. 56, 2(2009), pp. 616-630.

\section{Authors' addresses}

\section{Fatemeh Mohammadi Amiri}

Department of Information Technology Management,

Alzahra University, Tehran, Iran

Email: f mohammadiamiri@yahoo.com

\section{Ameneh Khadivar}

Assistant Professor of Management Department,

Alzahra University, Tehran, Iran 